\title{
Digital Media Preferences of Hostel Backpacker Consumer in Bandung Using Recommendation Score
}

\author{
Aditia Sovia Pramudita \\ Program Studi D4 Logistik Bisnis, Politeknik Pos Indonesia \\ Email: aditiasovia@poltekpos.ac.id
}

\begin{abstract}
Abstrak
Industri pariwisata di Indonesia merupakan industri yang berpotensi untuk tumbuh di masa depan. Akomodasi adalah salah satu faktor pendukung penting dalam rangka mengembangkan industri pariwisata. Sektor akomodasi diprediksi akan bersaing ketat. Hostel sebagai salah satu pilihan akomodasi juga perlu dikembangkan untuk memenuhi segmen akomodasi berbiaya rendah. Untuk bertahan di industri ini, praktisi hostel harus hati-hati dalam memilih saluran promosi dan distribusi mereka. Pada era modern ini, media digital menjadi salah satu pilihan saluran yang paling disukai karena dianggap tanpa biaya. Meskipun demikian, penggunaan saluran digital harus dipertimbangkan dengan hati-hati. Pilihan saluran digital yang salah dapat menyebabkan hilangnya peluang penjualan yang merupakan kerugian bagi perusahaan. Penelitian ini dilakukan di Bandung dengan fokus pada konsumen hostel. Rekomendasi skor digunakan sebagai metode untuk menganalisa data. Hasil penelitian ini adalah rekomendasi untuk saluran promosi dan saluran distribusi. Instagram dianggap sebagai saluran promosi yang paling direkomendasikan untuk konsumen hostel. Sementara untuk saluran distribusi, Agoda dianggap sebagai saluran distribusi yang paling direkomendasikan untuk konsumen hostel.
\end{abstract}

Kata Kunci: Hostel, Online Travel Agent, Media Digital, Skor Rekomendasi

\begin{abstract}
The tourism industry in Indonesia is potential growth in the future. Accommodation is one of the important supporting factors in order to develop the tourism industry. The accommodation sector is predicted to compete tightly. Hostel as one of accommodation selection also needs to be developed to fulfill a low-cost accommodation segment. In order to survive in this industry, Hostel practitioner should carefully choose their distribution channel. In this era, digital media become one of the most preferable channel selection since it is considered costless. Unsuitable digital channel selection can lead into opportunities lost sales for the company. This research is conducted in Bandung focusing on Hostel consumers. Recommendation score is used as a method to analyze the data. The result of this research, for promotional channel Instagram is considered as the most recommended promotional channel for hostel consumers. While for the distribution channel, Agoda is considered as the most recommended distribution channel for hostel consumer.
\end{abstract}

Keywords: Hostel, Online Travel Agent, Digital Media, Recommendation Score

\section{INTRODUCTION}

The tourism industry in Indonesia predicted to be one of the economic pillars. Those things are supported by the investment growth in Indonesia which tourism and e-commerce have the highest growth among other industries (Badan Koordinasi Penanaman Modal, 2018). Furthermore, the tourism industry also is already capable to gain 20 million foreign tourists and 275 million domestic tourists in 2018 (Pramudita, 2019). 
Bandung is one of the preferable tourism destinations for either domestic or foreign tourists. Bandung, both urban and suburban areas, is already had a good infrastructure especially related to tourism. Bandung tourism can be split into two categories which are inner-city tourism and outer city tourism. Inner-city tourism is related to historical and shopping attractions, while outer city tourism is related to nature tourism. Based on that fact, Bandung becomes one of the favorite tourism destinations (CNN Indonesia, 2015). Based on Indonesia Statistics Bureau, the number of tourists who visited Bandung can be seen in table 1 .

Table 1 Number of Tourist in Bandung

\begin{tabular}{|c|c|c|c|}
\hline \multirow{2}{*}{ Year } & \multicolumn{2}{|c|}{ Tourist } & \multirow{2}{*}{ Number } \\
\cline { 2 - 3 } & Foreign & Domestic & \\
\hline 2011 & 225.585 & 6.487 .239 & 6.712 .824 \\
\hline 2012 & 176.855 & 5.080 .584 & 5.257 .439 \\
\hline 2013 & 176.432 & 5.388 .292 & 5.564 .724 \\
\hline 2014 & 180.143 & 5.627 .421 & 5.807 .564 \\
\hline 2015 & 183.932 & 5.877 .162 & 6.061 .094 \\
\hline 2016 & 173.036 & 4.827 .589 & 5.000 .625 \\
\hline
\end{tabular}

Source: (Badan Pusat Statisik, 2018)

Accommodation as one of supporting tourism factor is also important. Based on Indonesia Statistics Bureau, in 2016 there are around 6 thousand rooms in Bandung.

Table 2 Number of Room in Bandung 2016

\begin{tabular}{|l|c|c|}
\hline \multicolumn{1}{|c|}{ Classification } & Number & Room \\
\hline 5 Stars Hotel & 9 & 1.870 \\
\hline 4 Stars Hotel & 32 & 3.651 \\
\hline 3 Stars Hotel & 42 & 3.507 \\
\hline 2 Stars Hotel & 25 & 1.500 \\
\hline 1 Star Hotel & 10 & 382 \\
\hline Unclassified & 218 & 6.041 \\
\hline
\end{tabular}

Source: (Badan Pusat Statisik, 2018)

The amount of accommodation in Bandung is increasing from time to time. Even though, the growth of tourists is not in line with the growth of accommodation. This condition becomes a problem for accommodation practitioners. In 2017, the occupancy rate of the hotel is around $40-50 \%$ on weekdays and $80 \%$ at the weekend (Pikiran Rakyat, 2018). At this moment, the occupancy rate considers still potential. Even though, in the future, it can be very tight concerning the growth of accommodation in Bandung.

Furthermore, the global condition itself regarding healthy issues also become a problem in the tourism industry. Since coronavirus is spreading in early 2020, the tourism industry in the world, especially in Indonesia, is decreased sharply (Rosana, 2020). Every practitioner in the tourism industry is trying to boost their sales through many efforts (Khairunnisa, 2020). 
Accommodation practitioner also needs to reevaluate their efforts regarding their rooms selling to survive.

The development of the tourism industry is related to the development of Information, Communication, and Technology (ICT) in Indonesia (Bisma \& Pramudita, 2019). The growth of online travel agents (OTA) as a new business model in the tourism industry, it became one of the main factors in tourism industry growth. Online travel agents held part as a digital distribution channel as well as the digital promotion channel for tourism industry practitioners. Those conditions become an indication that digital media has an important part in the growth of the tourism industry.

The use of digital media in the accommodation sector is to sell the room. Even though, digital media also can be used to promote the service. Digital media usage in accommodation is usually in company website form, social media, or through an online travel agent ( $\mathrm{Li}$-ming \& Wai, 2013). Based on a survey, $71.44 \%$ of the consumer is already used OTA to buy a room in 2018 (Daily Social Id, 2018). It shows that OTA held a significant role in room selling. The main problem of digital media usage in accommodation is practitioner was not certain which media selection can be used to promote or only selling.

There is a concept in marketing which is called Awareness, Interest, Desire, and Action (AIDA) in online media usage (Johar, 2015). AIDA is explaining the step of consumer behavior in the buying process toward promotion media. Every media has its function such as promotion or distribution channel. This research is focusing on the evaluation of digital media function by the hostel in Bandung with a recommendation score method. The result of this research can be a consideration for the accommodation practitioner to determine which digital media should be used based on company purposes (promotion or distribution).

\section{RESEARCH METHODOLOGY}

This research is conducted in Bandung city area focusing on hostel consumers. Referring to Isaac and Michael sampling table, sample that is gathered is 250 samples which is gathered from December 2019 until February 2020.

Recommendation score is used to measure digital media performance based on the AIDA concept. This recommendation score method is using six aspects Keller approach as the basis of his theory. This method was later developed by Nasution (2014) due to the weakness of the methods that have already been developed by other researchers (Pramudita, 2017). At the first time, recommendation score is used to measure the effectiveness of promotion media. In this case, recommendation score is used to measure the effectiveness of online distribution channel. Recommendation score is a customer evaluation of the effectiveness of marketing communication channels following the customer experience in using the channel to get some information. Recommendation score is obtained by changing customer evaluations using the formula in equation 1. Customer evaluation consists of positive and negative assessments. A positive assessment is given if a positive assessment is greater than a negative rating vice versa. The result is divided by the total sample so that a fair comparison can be made between channels.

$$
\text { Recommendation Score }=\frac{\text { Positive Recommendation }}{\text { Negative Recommendation }} / \text { Total Sample }
$$


The equation above shows that the greater the recommendation of channels in performing certain roles (ie disseminate information more specific), means the better channel in performing this role. If the value of recommendation score $>1$, then the respondents considered the channel is effectively acting as appropriate marketing communications. If $<1$ then the respondents considered the effectiveness of the marketing communication channel as inappropriate. Assessment value needs to be divided by the total sample due to the need to find out the average value of all respondents who filled recommendation scores to obtain the fair value of each media. This is necessary because the number of samples that fill each media can vary. The recommendation score of digital media is being crosstab with the age of the respondent to find suitable media purposes based on consumer ages. The procedure of digital media selection whether the score achieve its ideal condition or not can be seen in figure 1 . The procedure itself is adapted from the previous procedure which is created by Nasution (2014) with some adjustment according to business process of Hostel distribution channel selection Hostel itself.

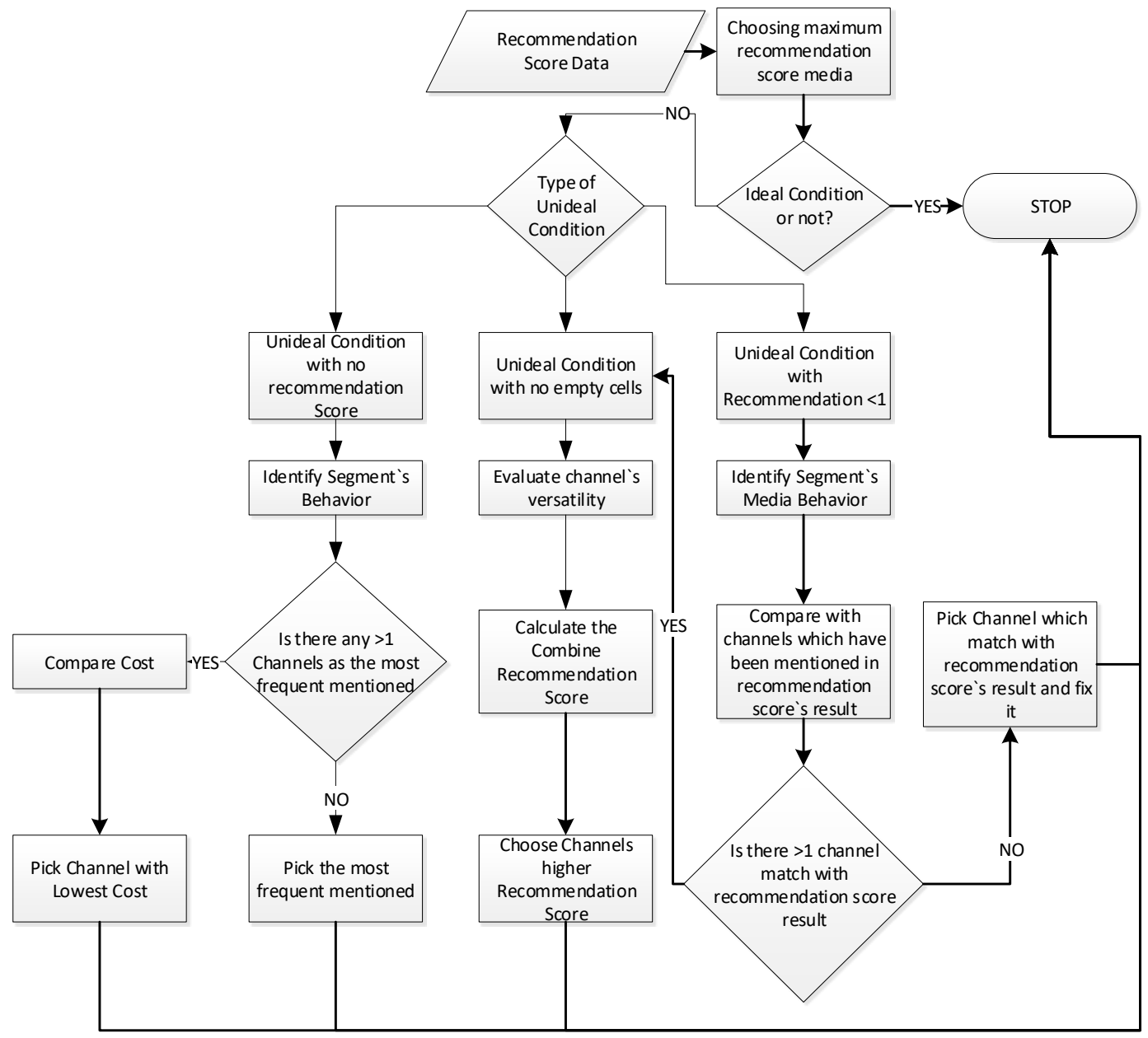

Figure 1 Digital Media Selection Procedure

Source: (Pramudita, 2017)

Digital media that is being evaluated is a website, social media, and OTA. The website is described as a company website. Social media is described as company Instagram and company 
Facebook. OTA is described as the selection OTA available in Indonesia referring to previous research which are Booking.com, Agoda, Hostelworld, Traveloka, Klikhotel, Pegi-pegi, and Expedia (Pramudita, 2019).

The first step was taken in calculating the recommendation score of each marketing communication channel and chose which channel with the value of the highest recommendation score. The next step is determining whether the results of the recommendation scores are in ideal condition or not. The ideal condition is achieved when the entire segment can be covered by a channel with a maximum value of recommendation score.

There are three conditions which are not ideal conditions occur in a segment that contains one or more channels with the same maximum value of recommendation score, there is a segment that is not covered by any channel, and there is a segment with a maximum value of recommendation score $<1$.

For the first unideal condition, if there are one or more channels with the same maximum value of recommendation scores then it needs to be checked on a channel, with the same maximum value of the same recommendation, its versatility. After checking the versatility, then combine the value of the recommendation score from each of the channel then the channel with the recommendation with a larger value of the channel is selected. For the second unideal condition, when there is a segment that is not covered by any channel, it is necessary to check how the behavior of the segment. If there is more than one channel is often referred by the segment, then it needs to be checked from cost per thousand of the channels (CPM). The purpose of the CPM metric is to compare the costs of advertising campaigns within and across different media. A typical advertising campaign might try to reach potential consumers in multiple locations and through various media. The cost per thousand impressions (CPM) metric enables marketers to make cost comparisons between these media, both at the planning stage and during reviews of past campaigns (Farris, Bendle, \& Reibstein, 2010).CPM is capable to see the effectiveness of media and it is suitable to determine the effectiveness of media. The formula for calculating the CPM is:

$$
\mathrm{CPM}=\text { cost } /(\text { target audience } / 1000)
$$

Furthermore, it can be seen which channel selection produces a higher value, but with the lowest cost. If there is only one channel that is often called then the channel is exactly chosen as an effective channel to cover that segment. For the third unideal condition, if there is a segment with a maximum value of the recommendation score of less than 1 then it is necessary to identify the behavior of that segment and compared the channel preferences of the segment with the recommendation score value. If there is only one channel that is suitable to cover the segment, then the effectiveness of the channel should be increased, but if there is more than one channel that matches the recommendation score then it must be entered into the procedure which is not ideal condition occurs when a segment has the same a maximum value of recommendation score.

\section{RESULT AND DISCUSSION}

The result of this research is divided based on the AIDA concept. Based on the previous research, the AIDA concept is divided into two which are AI for promotion purpose and DA for selling purpose (digital distribution channel). 
Table 3 Recommendation Score Result

\begin{tabular}{|l|r|r|r|r|r|r|r|r|}
\hline \multirow{2}{*}{ Digital Media } & \multicolumn{6}{|c|}{ Awareness and Interest } & \multicolumn{4}{c|}{ Desire and Action } \\
\cline { 2 - 10 } & $\begin{array}{c}17-25 \\
\text { y.o }\end{array}$ & $\begin{array}{c}26-35 \\
\text { y.o }\end{array}$ & $\begin{array}{c}36-45 \\
\text { yo }\end{array}$ & $\begin{array}{c}> \\
\text { y.o }\end{array}$ & $\begin{array}{c}17-25 \\
\text { y.o }\end{array}$ & $\begin{array}{c}26-35 \\
\text { y.o }\end{array}$ & $\begin{array}{c}36-45 \\
\text { yo }\end{array}$ & $\begin{array}{c}\text { y.o } \\
\text { y.o }\end{array}$ \\
\hline $\begin{array}{l}\text { Company } \\
\text { Website }\end{array}$ & 4.23 & 10.50 & 11.50 & 0.88 & 1.91 & 2.96 & 3.16 & 1.07 \\
\hline $\begin{array}{l}\text { Company } \\
\text { Instagram }\end{array}$ & 16.21 & 17.60 & 9.49 & 0.96 & 2.71 & 2.03 & 2.60 & 1.27 \\
\hline $\begin{array}{l}\text { Company } \\
\text { Facebook }\end{array}$ & 10.52 & 3.95 & 9.08 & 3.75 & 3.16 & 0.75 & 1.20 & 0.00 \\
\hline Booking.com & 1.54 & 1.41 & 3.95 & 2.31 & 2.10 & 1.82 & 0.38 & 2.50 \\
\hline Agoda & 2.04 & 2.36 & 0.96 & 1.85 & 8.20 & 4.85 & 7.25 & 1.02 \\
\hline Hostelworld & 2.14 & 2.67 & 3.87 & 1.68 & 12.55 & 2.10 & 3.40 & 1.45 \\
\hline Traveloka & 2.46 & 2.86 & 4.18 & 1.58 & 10.26 & 1.78 & 2.58 & 4.48 \\
\hline Klikhotel & 4.95 & 4.12 & 1.67 & 0.00 & 3.57 & 3.25 & 2.03 & 0.35 \\
\hline pegi-pegi & 1.92 & 2.46 & 1.85 & 0.00 & 1.69 & 1.56 & 0.75 & 0.38 \\
\hline Expedia & 0.75 & 1.68 & 1.67 & 0.00 & 1.15 & 1.96 & 0.69 & 4.48 \\
\hline Max Value & 16.21 & 17.60 & 11.50 & 3.75 & 12.55 & 4.85 & 7.25 & 4.48 \\
\hline
\end{tabular}

Based on the result above, all of the results considered in an ideal condition so it can be proceed to the next step.

To increase the awareness and interest of respondents, company websites and company social media are became the proposed digital media based on the recommendation score method. Furthermore, to increase desire and action, OTA is the only digital media that is being trusted by the respondent. Even though, not all of OTA that is being recommended, only Agoda, Hostelworld, and Traveloka.

To increase awareness and interest, for ages 17 - 25 and 26 - 35 years old, company Instagram is considered effective, for 36 - 45 years old company website is considered as effective, and for more than 45 years old company Facebook is considered as effective. While to increase desire and action, for ages 17 - 25 years old, Hostelworld is considered as effective, for 26 35 and 36 - 45 years old, Agoda is considered as effective, and for more than 45 years old, Traveloka is considered as effective.

The hostel is a special kind of accommodation compared to the hotel. The hostel is well known in youngsters and young mature since the hostel price is relatively low. Even though, it is not ruled out the possibility of the mature consumer to stay in Hostel.

The conclusion of this research can be seen in table 4 .

Table 4 Conclusion

\begin{tabular}{|l|c|c|c|c|c|c|c|c|}
\hline \multirow{2}{*}{ Digital Media } & \multicolumn{4}{|c|}{ Promotion Channel } & \multicolumn{4}{c|}{ Distribution Channel } \\
\cline { 2 - 8 } & $\begin{array}{c}17-25 \\
\text { y.o }\end{array}$ & $\begin{array}{c}26-35 \\
\text { y.o }\end{array}$ & $\begin{array}{c}36-45 \\
\text { yo }\end{array}$ & $\begin{array}{c}>45 \\
\text { y.o }\end{array}$ & $\begin{array}{c}17-25 \\
\text { y.o }\end{array}$ & $\begin{array}{c}26-35 \\
\text { y.o }\end{array}$ & $\begin{array}{c}36-45 \\
\text { yo }\end{array}$ & $\begin{array}{c}>45 \\
\text { y.o }\end{array}$ \\
\hline $\begin{array}{l}\text { Company } \\
\text { Website }\end{array}$ & & & $\checkmark$ & & & & & \\
\hline
\end{tabular}




\begin{tabular}{|l|c|c|c|c|c|c|c|c|}
\hline \multirow{2}{*}{ Digital Media } & \multicolumn{5}{|c|}{ Promotion Channel } & \multicolumn{3}{c|}{ Distribution Channel } \\
\hline & $\begin{array}{c}17-25 \\
\text { y.o }\end{array}$ & $\begin{array}{c}26-35 \\
\text { y.o }\end{array}$ & $\begin{array}{c}36-45 \\
\text { yo }\end{array}$ & $\begin{array}{c}>45 \\
\text { y.o }\end{array}$ & $\begin{array}{c}17-25 \\
\text { y.o }\end{array}$ & $\begin{array}{c}26-35 \\
\text { y.o }\end{array}$ & $\begin{array}{c}36-45 \\
\text { yo }\end{array}$ & $\begin{array}{c}>45 \\
\text { y.o }\end{array}$ \\
\hline $\begin{array}{l}\text { Company } \\
\text { Instagram }\end{array}$ & $\checkmark$ & $\checkmark$ & & & & & & \\
\hline $\begin{array}{l}\text { Company } \\
\text { Facebook }\end{array}$ & & & & $\checkmark$ & & & & \\
\hline Booking.com & & & & & & & & \\
\hline Agoda & & & & & & $\checkmark$ & $\checkmark$ & \\
\hline Hostelworld & & & & & $\checkmark$ & & & \\
\hline Traveloka & & & & & & & & $\checkmark$ \\
\hline Klikhotel & & & & & & & & \\
\hline pegi-pegi & & & & & & & & \\
\hline Expedia & & & & & & & & \\
\hline
\end{tabular}

\section{Promotion Channel}

Based on the result above, Hostel practitioners should use a company website, Instagram, and Facebook to promote their services. Even though, hostel practitioner also needs to define their customer segment. If Hostel is targeting young consumers (17-35 years old) Instagram is the best choice among other promotional channels. While for mature consumers, websites and Facebook can be a choice for the promotional channel. For future research, it should be considered other promotional non-digital media, especially for a mature consumer segment.

\section{Distribution Channel}

The distribution channel in accommodation has a purpose to sell the room (Pramudita, 2019). It has a different function compared to the promotion channel. For a youngster (17 - 35 years old) Agoda and Hostelworld are the best media selection for the distribution channel. While for mature consumer Agoda and Traveloka are considered as a recommended distribution channel.

Overall, company Instagram is considered as recommended promotion channel since it can cover 2 consumer segments which are $17-25$ years old and $26-35$ years old segment. While Agoda is considered as a recommended distribution channel since it can cover 2 consumer segments which are 26- 35 years old and 36 - 45 years old segment. Even though, Hostel practitioner also needs to considered Hostelworld since Hostel consumer is a youngster.

\section{CONCLUSION}

Hostel practitioners should consider using Instagram as their promotional channel since it is considered effective to promote Hostel services. Even though, Instagram is not suitable to change consumer perception into buying services. Hostel practitioners should consider using Agoda as their distribution channel to sell their services.

\section{REFERENCES}

Badan Koordinasi Penanaman Modal. (2018). Kepala BKPM: Investor Minati Sektor Pariwisata RI. Retrieved from https://www.bkpm.go.id/id/publikasi/detail/berita/kepalabkpm-investor-minati-sektor-pariwisata-ri

Badan Pusat Statisik. (2018). Bandung Municipality in Figures. Retrieved from 
https://bandungkota.bps.go.id/publication/download.html?nrbvfeve=YTI3ODJhZTYyM DQyYjFhZWU5MWZiNGJj\&xzmn=aHR0cHM6Ly9iYW5kdW5na290YS5icHMuZ28 uaWQvcHVibGljYXRpb24vMjAxOC8wOC8xNi9hMjc4MmFINjIwNDJiMWFlZTkxZ mI0YmMva290YS1iYW5kdW5nLWRhbGFtLWFuZ2thLTIwMTguaHRtbA\%3D\%3D \&twoadfnoarfeauf=MjAxOS0wNy0xOCAxODo0NTozNQ\%3D\%3D

Bisma, M. A., \& Pramudita, A. S. (2019). Analisa Minat Pembelian Online Konsumen Pada Saluran Distribusi Digital Marketplace Online di Kota Bandung. Competitive, 14(2), 36 44. https://doi.org/http://dx.doi.org/10.36618/competitive.v14i2.617

CNN Indonesia. (2015). Survei: Bandung Kota Terfavorit Wisatawan Se-ASEAN. Retrieved from https://www.cnnindonesia.com/gaya-hidup/20150210162426-269-31086/surveibandung-kota-terfavorit-wisatawan-se-asean

Daily Social Id. (2018). Laporan DailySocial: Survey Online Travel Agencies (OTA) 2018.

Farris, P. W., Bendle, N., \& Reibstein, D. J. (2010). Marketing Metrics: The Definitive Guide to Measuring Marketing Performance. Pearson Education.

Johar, D. S. (2015). EFEKTIFITAS IKLAN ONLINE ( Survei pada Pembeli di Toko Online Adorable Project ). Jurnal Administrasi Bisnis, 26(1), 1-10.

Khairunnisa, S. N. (2020). Virus Corona, ASTINDO Travel Fair 2020 Jadi Upaya Genjot Industri Pariwisatar Tempo. Retrieved from https://travel.kompas.com/read/2020/02/12/190145927/virus-corona-astindo-travel-fair2020-jadi-upaya-genjot-industri-pariwisata

Li-ming, A. K., \& Wai, T. B. (2013). Exploring Consumers' Attitudes and Behaviours toward Online Hotel Room Reservations, 3, 6-11. https://doi.org/10.5923/c.economics.201301.02

Pikiran Rakyat. (2018). Okupansi Hotel di Jawa Barat Terus Menurun. Retrieved from https://www.pikiran-rakyat.com/ekonomi/2019/06/18/okupansi-hotel-di-jawa-baratterus-menurun

Pramudita, A. S. (2017). MODEL SALURAN INTEGRATED MARKETING COMMUNICATION BRI. Jurnal Logistik Bisnis, 7(1), 12-23.

Pramudita, A. S. (2019). PENGUKURAN PERFORMA DIGITAL DISTRIBUTION CHANNEL TERHADAP KEPUTUSAN PEMBELIAN HOSTEL PADA PINISI BACKPACKER DENGAN MULTINOMIAL LOGISTIC REGRESSION. Jurnal Competitive, 14(2).

Rosana, F. C. (2020). Virus Corona, Wishnutama: Kerugian Devisa Pariwisata Capai 54,8 T. Tempo. Retrieved from https://bisnis.tempo.co/read/1303758/virus-corona-wishnutamakerugian-devisa-pariwisata-capai-548-t 